\title{
How Firm Strategies Impact Size of Partner-Based Retail Networks: Evidence from Franchising
}

\begin{abstract}
How do firms' partnering strategies impact the size of their partner-based retail networks? We draw on agency theory to address this question in the context of franchising. Our econometric analyses (based on nine years of longitudinal balanced panel data) include assessment of data nonstationarity and estimation of a dynamic panel data model that accounts for unobserved heterogeneity and endogeneity. Our findings indicate that franchisee network size is driven more by franchisor strategies that mitigate agency costs than by strategies that simply lower entry and ongoing costs and barriers for franchisees.
\end{abstract}




\section{How Firm Strategies Impact Size of Partner-Based Retail Networks: Evidence from Franchising}

\section{INTRODUCTION AND LITERATURE REVIEW}

Although there are many different types of partner-based retail systems (including licensing and multi-level marketing), franchising is the most popular manifestation of this format. Since its infancy in the early 20th century, franchising has had a substantial impact on retailing landscapes across the world and enabled small firms to expand their businesses. According to Michael (1996), by the mid-1990s, franchise systems accounted for $30 \%$ to $40 \%$ of sales in the U.S. for a diverse range of industries. Recent estimates (Dant et al 2011) indicate that there are over 3000 franchise systems in the USA, accounting for 901,093 franchisees, employing approximately 18 million people and generating an economic output of $\$ 2.1$ trillion (equal to about $40.9 \%$ of the U.S. retailing sector). Additionally, franchising is a key international expansion format for U.S. firms (Michael 2003).

While there are many different types of franchise systems, business format franchise systems $^{2}$ account for the largest number of establishments, jobs, payroll and output in the U.S. (Price Waterhouse Coopers 2008). The emergence of business format franchising as an important retail format has made it an attractive domain for the study of factors driving the size of partner-based retail networks. The performance and profitability of these networks is contingent on attracting effective partners to expand the market footprint of the retail system. Thus, an understanding of the factors and decisions that impact partner network size is of value to not only business format franchisors but also other firms with partner-based retail networks.

\footnotetext{
${ }^{2}$ Business format franchise systems (for example, McDonald's, Pizza Hut, KFC, Dunkin' Donuts, Applebee's, H \& R Block, Century 21 and ServiceMaster) are franchise systems where the contractual arrangement "includes not only the product, service and trademark, but the entire business format itself - a marketing strategy and plan, operating manuals and standards, quality control, and continuing two way communication" (U.S. Department of Commerce 1987, page 3). In return for the right to use the franchisor's business format, a franchisee typically pays an initial upfront franchisee fee as well as ongoing royalty and advertising fees (Dant and Berger 1996).
} 
In this paper, we build on extant literature and enhance understanding of what drives the size of franchisee networks through agency theory-based reasoning and rigorous econometric analyses that capture the effects of a rich set of franchisor partnering strategies. The importance of this endeavor is underscored by substantial variation observed across franchise systems in the size and growth of franchisee networks and total networks ${ }^{3}$ (Blair and Lafontaine 2005; Perrigot 2004; Stanworth 1996) as well as calls for scholarly explanations of differing performance levels across franchise systems (for example, Gillis and Castrogiovanni 2012).

We focus on the size of the business format franchisor's franchisee network for two primary reasons. One, we observe considerable heterogeneity in the sizes of franchisee networks across franchisors and want to understand why some franchisors have much larger franchisee networks than others. Specifically, we examine how differences in franchisor strategies that affect franchisees explain variations in the size of their franchisee networks. Given the positive externalities as well as economies of scale generated by a large franchisee network, this is a question of considerable managerial importance and relevance to firms. Second, we view franchisee network size as a key measure of franchisor performance, particularly for assessing a franchisor's partnering strategies. We observe four traditional approaches to performance measurement in the extant franchising literature: attitudinal and perceptual measures; archival, internal, sales data-based measures; archival, publicly available financial data-based measures; and survival and failure rates. While these approaches yield important insights about franchisor performance, each approach has some limitations (which are summarized in Table 1). Gillis and Castrogiovanni (2012) call for performance measures (other than survivability) that apply across industries and can be obtained for both private and publicly held franchisors.

\footnotetext{
${ }^{3}$ For expositional clarity, we use the term 'franchisee network' to refer to the network of franchisees in the chain and the term 'total network' to refer to the totality of franchised and franchisor-owned outlets in the chain.
} 


\section{Insert Table 1 about here}

A fifth approach, the one we adopt in this paper, measures franchising performance in terms of the number of retail outlets in the franchise system. This approach recognizes the strong positive relationship between network size and system sales and between system sales and firm value (Kling et al 2009), includes both privately and publicly held franchisors, uses archival data, can be obtained for franchisors across various industries and emulates the dominant tradition for measuring performance in the franchising literature. Dant et al (1996) report that a majority of studies of performance in franchise systems use measures based on the number of outlets in the system. However, many of these studies (for example, Castrogiovanni and Justis 2002; Dant et al 2007; Kosová and Lafontaine 20104; Sen 1998; Shane 1996; Shane et al 2006) focus on the overall system (including franchisor-owned outlets). This approach is appropriate when the goal is to evaluate overall franchisor performance. However, many franchisor strategies are designed to specifically impact franchisees and drive the size of the franchisee network rather than the total network. Hence, it is more appropriate to consider franchisee network size than total network size when assessing performance implications of these franchisor strategies. Overall system size is more likely to be affected by factors other than a franchisor's franchisee-focused strategies. Therefore, given our substantive aims, we chose to focus on the number of franchised outlets in a franchise system as our measure of franchisor performance.

The importance of understanding how strategic decisions made by a franchisor influence the size of its franchisee network is reinforced by divergent perspectives on drivers of network size. Conventional wisdom among practitioners has often emphasized financial cost-based ideas

\footnotetext{
${ }^{4}$ Kosová and Lafontaine (2010) also measure performance of just the franchised component of franchised systems. However, they measure this performance in terms of exit from franchising and the growth rate of the franchisee network rather than franchisee network size. Instead, they use network size as an explanatory variable. Note that extant research (for example, Dant et al 2007; Shane et al 2006) has shown that other explanatory variables used by Kosová and Lafontaine (2010) are also predictors of network size.
} 
that a franchisor can develop a large franchisee network by lowering entry and ongoing costs for prospective franchisees (for example, Chun 2008; Fell 2011). This viewpoint is echoed in Shane et al's (2006) study of drivers of total network size for young franchisors. In contrast, agency theory submits that franchisee network size may be influenced by the extent to which franchisor strategies reduce agency problems (moral hazard and adverse selection). Such actions create value for extant and prospective franchisees (Grünhagen and Dorsch 2003; Kaufmann and Stanworth 1995).

There are a relatively small number of studies that investigate drivers of growth and number of outlets for the total system and one study that examines franchisee network growth. Sen (1998) and Castrogiovanni and Justis (2002) study correlates of overall network growth. Dant et al (2007) assess correlates of total network size as well as the breadth and depth of distribution. Shane and his colleagues examine factors driving the size and growth of total networks for new franchisors - Shane (1996) studies the association between the use of franchising and total network growth while Shane et al (2006) consider the effects of some additional pricing policy and strategic control decisions on total system size. Kosová and Lafontaine (2010) examine how chain age and size influence survival and growth rates for the total network as well as for the franchisee network. None of these studies assess drivers of franchisee network size.

In this paper, we make substantive contributions to the extant literature in two ways. First, we focus specifically on understanding what influences the number of franchised outlets in a franchise system. This is in contrast to the focus on total network size in Shane et al (2006) and Dant et al (2007). In our view, since the franchisor strategies examined in these studies relate to franchising and franchisees, franchisee network size is a more appropriate dependent variable than total network size. Second, we enhance the comprehensiveness of our study by considering a broad set of franchisors and range of franchisor decision variables. We consider franchisors of all 
sizes and ages in our sample. This is in contrast to Shane (1996) and Shane et al (2006) who focus on new franchisors only. We include franchisors from multiple industries, in keeping with the call from Gillis and Castrogiovanni (2012) to consider industries other than the restaurant industry. While Kosová and Lafontaine (2010) cover franchisors across industries and ages, they use an unbalanced panel data set. We use a balanced panel data set that includes nine years of longitudinal data from multiple industries. ${ }^{5}$ By using a balanced rather than an unbalanced panel, we can undertake econometric analyses that would otherwise not be feasible and which add rigor to our insights. Additionally, we cover a larger set of franchisor decision variables than Shane et al (2006) and Kosová and Lafontaine (2010) and this enhances the prescriptive value of our work. We adopt an econometric modeling approach that checks for nonstationarity in the data and uses dynamic panel generalized method of moments (GMM) estimation that accounts for unobserved heterogeneity and endogeneity. We use the Arellano and Bover (1995) continuously updated estimator with White period robust Standard Errors (SEs) that are robust to innovations that have time series correlation structure that varies by cross-section. In the Arellano-Bover method, the GMM weight matrix and coefficients are updated (that is, re-estimated iteratively) until convergence. This approach often yields estimates that have better finite sample properties than approaches such as the Arellano and Bond (1991) two step method (where the GMM weight matrix is updated once and the final coefficients are then estimated) and the two stage least squares fixed effects approach used by Shane et al (2006).

Our empirical analyses reveal statistically significant support for seven of our eight hypotheses - a higher Royalty Rate, higher Advertising Fee, smaller Percentage of Owned Outlets, greater Complexity, longer Concept Development Time, greater use of Qualification

\footnotetext{
${ }^{5}$ A balanced panel includes data for every year for each firm in the panel. In contrast, in an unbalanced panel, observations may be missing for one or more years for one or more firms in the panel.
} 
procedures, and more Structural Flexibility are associated with larger franchisee network size. Note that many variables that had been previously ignored in explanations of system size (for example, Complexity, Concept Development Time, Qualification, and Structural Flexibility) are found to have a statistically significant effect on franchisee network size. Our empirical findings counter the conventional wisdom among practitioners that key drivers of a franchisor's franchisee network size are strategies that simply lower entry and ongoing costs and barriers for franchisees. Instead, it is the agency cost reducing properties of a franchisor's partnering strategies that primarily drive franchisee network size. We contribute to agency theory research in franchising by explaining how the same set of franchisor strategies have implications for both the adverse selection (concerning prospective franchisees) and moral hazard (revolving around extant franchisees) problems in the system and describing how franchisor strategies designed to directly impact one problem may also indirectly affect the other.

In the next section, we present our overall theoretical approach. This is followed by our hypotheses and the specific theoretical rationales underlying them. We then describe our data and operationalizations. The subsequent section contains details of our estimation procedure and empirical results. We conclude with a discussion of the theoretical and managerial implications of our results, limitations and possible directions for future research on this topic.

\section{THEORY}

There are multiple perspectives that can be used to understand factors that influence franchisee network size. Conventional wisdom among practitioners is often grounded in the idea that franchisee network size is driven by lowering entry and ongoing financial costs and barriers for prospective franchisees (for example, Chun 2008; Fell 2011). We adopt a different view, 
where the size of the franchisee network depends on the competitiveness and profitability of the business format for the franchisor as well as for existing and prospective franchisees. This, in turn, is based on franchisor partnering strategies that mitigate agency costs associated with prospective and extant franchisee relationships and help the franchisor safeguard and enhance the business format. Our view is primarily informed by insights from agency theory, a prominent theoretical perspective that has been widely used to study franchising issues as indicated in multiple metaanalyses (Combs and Ketchen, Jr. 2003; Dant et al 1996) and literature reviews (Blair and Lafontaine 2005; Combs et al 2004; Combs et al 2011; Lafontaine and Slade 1997).

Agency theory focuses on the principal-agent exchange relationship where one party (agent) acts on behalf of another party (principal). It is concerned with addressing agency problems and costs that arise when information asymmetries exist between the agent and the principal and they have different interests (Arrow 1985; Bergen et al 1993; Eisenhardt 1989). Agency theory has been widely used to explain why firms choose to franchise instead of being vertically integrated (Blair and Lafontaine 2005). However, there are potential agency costs in a franchisor's relationships with extant and prospective franchisees as well. These agency costs can lead to underinvestment in advertising (Michael 2002) as well as lower overall system quality (Michael 2000). A franchisor's actions to mitigate the agency problems in its franchise system can safeguard and grow future rent streams for the system. By ensuring the entry of high quality franchisees into the system and minimizing free riding by extant organizations within the system, a franchisor can improve the competitive standing of its business format. Lower agency costs reduce the likelihood of business failure for individual franchisees (Michael and Combs 2008) and facilitate expansion of the franchisee network. Thus, we posit that franchisors are able to expand their franchisee networks through strategies that alleviate potential agency costs associated with these networks. 
Bergen et al (1993) note that agency problems can be broken down into two types:

precontractual (adverse selection or hidden information problems) and postcontractual (moral hazard or hidden action problems ${ }^{6}$ ). Adverse selection problems arise from precontractual information asymmetries between principals and agents and heterogeneity in the quality of the economic actors (Spence 1973) - the principal is not as well informed as a prospective agent about whether the latter has the qualities needed to successfully perform an agent's tasks. A franchisor's primary agency concerns regarding adverse selection revolve around prospective franchisees.

A franchisor can overcome the adverse selection problem and facilitate economic exchange (Bergen et al 1992). First, it can screen prospective franchisees. This is particularly effective when the franchisor can easily obtain information about characteristics of applicants that are good predictors of their future performance as franchisees. Dnes (1992) considers the franchise contract as a screening device. If costs of screening prospective franchisees are too high, a franchisor can consider creating signaling or self-selection opportunities for high quality prospective franchisees.

Note that precontractual information asymmetries and adverse selection problems can be bidirectional. Thus, a prospective franchisee may not be as well-informed as the franchisor about future prospects for the business format or whether the franchisor can effectively execute its responsibilities to the prospective franchisee once the latter joins the system. Consequently, a franchisor may undertake actions that serve as credible signals of its own quality to prospective franchisees so as to attract high quality applicants. ${ }^{7}$ Within the franchising context, Gallini and

\footnotetext{
${ }^{6}$ For expositional simplicity and consistency with the extant franchising literature, we hereafter refer to precontractual/hidden information agency problems as adverse selection problems and postcontractual/hidden action agency problems as moral hazard problems.

${ }^{7}$ An important distinction between quality signaling in the broader agency theory literature and franchisor quality signaling revolves around what constitutes 'quality'. In a general agency setting, quality often refers to fixed traits of the signaling entity that will impact the outcomes from the exchange relationship. In franchising, as suggested by Lafontaine (1993), franchisor quality is better viewed in terms of the future behavior of the franchisor. It is this future behavior, rather than exogenous franchisor characteristics, that will impact franchisee outcomes over the
} 
Lutz (1992) use theoretical modeling to examine such franchisor signaling through the level of dual distribution and the fee structure of the franchise contract. Franchisor signaling is empirically investigated by Lafontaine (1993), Michael (2009), Scott (1995) and Shane et al (2006).

Moral hazard problems arise in the postcontractual stage, where an agent may not act in the principal's best interests and, instead, engage in shirking or free riding on the efforts of the principal or other agents (Arrow 1985). The potential for moral hazard by the agent arises from a combination of three assumptions (Bergen et al 1992) - first, the agent is motivated by its selfinterest and its goals and risk preferences can differ from those of the principal; second, information asymmetries exist regarding the agent's actions and the principal operates under incomplete information; and third, realized outcomes are also impacted by environmental factors. Considerable attention is focused on the development of mechanisms that can prevent or reduce moral hazard by the agent (Bergen et al 1992). These mechanisms typically involve the creation of incentives to motivate the agent to pursue goals and outcomes consistent with the principal's interests (outcome-based control, as per Eisenhardt 1989) or the use of monitoring to collect more information about the agent's actions (behavior-based control, as per Eisenhardt 1989). A franchisor's primary moral hazard concerns largely revolve around extant franchisees. It is helpful to recognize that extant franchisees are not the only source of moral hazard in franchising. A franchisor undertakes advertising, brand building, product/service mix improvement, outlet quality monitoring and other activities on behalf of franchisees (Kaufmann and Stanworth 1995) and is, therefore, also a potential source of moral hazard. This view of two sided moral hazard (and the need to provide incentives to the franchisor) has found empirical support in the work of Lafontaine (1992) and Brickley (2002). This perspective is also reflected in 
conceptual explanations for franchising (Rubin 1978), game-theoretic models of franchising (Bhattacharya and Lafontaine 1995; Lal 1990; Mathewson and Winter 1985), and empirical reviews (Combs et al 2004; Lafontaine and Slade 1997). We adopt this two sided moral hazard perspective in the development of our hypotheses. Franchisor moral hazard is reduced when contractual fees give the franchisor an incentive to not shirk or free ride on the effort of franchisees. Franchisee moral hazard can be curbed by incentives for franchisees and the monitoring of franchisees. Additional extant research that focuses on antecedents and consequences of moral hazard in franchising (and the use of incentives or monitoring mechanisms to mitigate it) includes Brickley (1999), Brickley and Dark (1987), Combs and Ketchen, Jr. (1999a, 199b), Gillis et al (2011), Gonzalez-Diaz and Solis-Rodriguez (2012), Kidwell et al (2007), Michael (2000), Michael (2002), Shane (1996), Shane (1998), and Wu (1999).

Agency theory provides us with a theoretical framework that can jointly consider a franchisor's concerns regarding extant and prospective franchisees. Since we are examining multiple dyads (franchisor-extant franchisee; franchisor-prospective franchisee), we recognize that franchisor strategies designed to directly impact agency costs in one dyad may also indirectly affect agency costs in another dyad. A franchisor that rigorously screens prospective franchisees and signals its commitment to provide superior ongoing services to those who join the system is more likely to overcome the adverse selection problem and attract high quality potential franchisees. These high quality applicants are likely to succeed as franchisees once they join the franchise system and facilitate the expansion of the franchisee network (by increasing its attractiveness to other high quality prospective franchisees in the future). Franchisor strategies aimed at ensuring the entry of high quality franchisees into the system can also indirectly alleviate the moral hazard problem by allaying extant franchisee concerns about moral hazard by new 
members of the franchisee network. When a franchisor invests considerable effort in ensuring the entry of high-quality franchisees into the system, extant franchisees may perceive the franchisor to be less likely to free ride or shirk in the performance of its other functions. These two factors should motivate extant franchisees to eschew moral hazard and, instead, act in a manner that improves outcomes for the system and its members. This, in turn, reinforces the competitive standing of the franchise system and enables the subsequent expansion of the franchisee network.

A franchisor's strategies for structuring and managing exchange relationships with existing franchisees can directly mitigate the moral hazard problem by reducing franchisor and franchisee incentives for free riding. Such actions can also indirectly alleviate the adverse selection problem by signaling the franchisor's commitment to safeguard the quality of the business format to prospective franchisees. The attenuation of moral hazard within the franchise system strengthens the performance of the system as a whole, leading to lower failure rates among existing outlets. In addition, it reinforces the attractiveness of joining the franchisee network for prospective franchisees. The enhanced performance of outlets within the franchisee network and the increased appeal to prospective franchisees should lead to expansion of the franchisee network.

\section{HYPOTHESES}

In this section, we deductively develop a slate of eight hypotheses pertaining to the eight predictors of our dependent variable, franchisee network size. ${ }^{8}$ These predictors are franchisor strategies that impact the attractiveness of the franchise concept for prospective franchisees and the management of exchange relationships with extant franchisees: (1) Royalty Rate, (2) Advertising Fee, (3) Franchise Fee and Initial Investment, (4) Percentage of Owned Outlets, (5) Complexity,

\footnotetext{
${ }^{8}$ We are grateful to two anonymous reviewers whose insights have enabled us to strengthen the theoretical reasoning underlying our hypotheses.
} 
(6) Concept Development Time, (7) Qualification, and (8) Structural Flexibility. Our conceptual framework and hypotheses are summarized in Figure 1.

\section{Insert Figure 1 about here}

\section{$\underline{\text { Royalty Rate }}$}

The royalty rate (typically a percentage of sales) determines the share of a franchisee's revenues that go to the franchisor (Dant and Berger 1996). A lower royalty rate ensures that the franchisee keeps a higher share of the revenues, increasing the likelihood that the value of the franchise system to prospective franchisees will be high enough to attract them into the network. This rationale, used by Shane et al (2006), reflects the conventional wisdom among practitioners that lower entry and ongoing costs will facilitate franchisee network expansion. However, agency theory accommodates a positive relationship between the royalty rate and franchisee network size. Royalties are often viewed by franchisors and franchisees as payments in return for services rendered (Combs and Ketchen 2003, Lafontaine 1992, Sen 1993). Thus, within the range of royalty rates typically observed in franchising, a higher royalty indicates that superior levels of ongoing services (in terms of quality, reliability and/or magnitude) will be provided by the franchisor to franchisees. Shane (1998) notes that prospective franchisees may view the size of the royalty rate as an indicator of the franchisor's incentive to develop and safeguard franchise system assets. Prospective franchisees operate under conditions of imperfect information in evaluating different franchise business formats. Consequently, they may favorably view a higher royalty rate (relative to rates stipulated by other competing franchisors) as a signal of the superiority of ongoing services and support to be provided by the franchisor to them. Thus, a higher royalty rate may help mitigate the adverse selection problem from the perspective of a potential franchisee. 
A higher royalty may also reduce moral hazard by the franchisor and extant franchisees. Extant conceptual and theoretical modeling research in franchising concludes that a higher royalty rate gives the franchisor a greater stake in the ongoing performance of the franchise system and reduces franchisor moral hazard (Bhattacharyya and Lafontaine 1995; La1 1990; Mathewson and Winter 1985; Rubin 1978). Under these conditions, a franchisor is more likely to eschew free riding and live up to its commitments, in terms of training franchisees, developing new products and processes and enhancing brand equity. Brickley and Dark (1987) find that higher royalty rates give the franchisor greater incentives to monitor franchisees and enforce contractual provisions to prevent franchisee free riding. Thus, relatively higher royalty rates (when accompanied by commensurate increases in franchisee monitoring by the franchisor that outweigh increased franchisee incentives to free ride) can also lead to lower extant franchisee moral hazard. In doing so, they indirectly signal franchisor quality (in terms of future behavior of the franchisor and outcomes for the network) to prospective franchisees and facilitate franchisee network expansion.

Taken together, the arguments outlined above suggest that, within the range of royalty rates typically observed in franchising, a relatively higher royalty rate lowers the likelihood of exit by extant franchisees (because of reduced moral hazard by the franchisor and other franchisees) and increases the pool of qualified prospective franchisees keen to join the system (because of the franchisor's quality signaling). Hence, we posit that:

H1: $\quad$ The royalty rate is positively related to franchisee network size.

\section{Advertising Fee}

Franchisees pay an ongoing advertising fee to the franchisor, for use towards ongoing advertising and other brand building services. This fee is typically expressed as a percentage of franchised outlet revenue (Dant and Berger 1996). The rationale expressed in the development 
of H1 applies here as well. A relatively higher advertising fee (within the range of advertising fees typically observed in franchising) alleviates the adverse selection problem from the viewpoint of prospective franchisees. It serves as an indicator of the franchisor's commitment to maintain and build brand equity through ongoing advertising services. High brand equity enhances attractiveness of the franchise concept to end-users and makes participation in the franchise system less risky for a prospective franchisee. Guilloux et al (2004) and Peterson and Dant (1990) find that the brand equity of the franchise system is one of the most important criteria used by prospective franchisees in selecting a franchise system. Guilloux et al (2004) note that prospective franchisees care about not only the franchisor's brand name but also the franchisor's efforts to maintain develop the brand name through advertising.

A relatively higher advertising fee also creates safeguards against franchisor moral hazard, since it gives the franchisor a larger share of franchisee revenues and, therefore, a greater stake in the continued success of its franchisees. Brickley (1999) examines the association between the existence of externalities (and the potential for moral hazard) and the presence of advertising fees in franchise contracts. He concludes that the inclusion of mandatory advertising fees effectively sets one of the franchisee's inputs (advertising expenditure) at a minimum level and thereby removes one of the dimensions for potential franchisee moral hazard. ${ }^{9}$

The above arguments suggest that the presence and level of advertising fees have a positive impact on the reduction of adverse selection and moral hazard in the franchise system and, therefore, on franchisee network size:

H2: $\quad$ The advertising fee is positively related to franchisee network size.

\footnotetext{
${ }^{9}$ The presence and level of an advertising fee reduces the franchisee's share of outlet revenues. Prima facie, this creates greater incentives for franchisee free riding on other inputs. However, this incentive may be offset if the revenue creating impact of the franchisee's inputs is amplified by the greater levels of advertising and brand building undertaken by the franchisor (as a consequence of the higher advertising fee).
} 


\section{Franchise Fee and Initial Investment}

The franchise fee represents the fixed fee paid by a franchisee to the franchisor at the start of the business relationship. Franchisors also require franchisees to pay an initial investment amount, in exchange for initial fixed costs and services (for example, real estate, insurance, building, furnishing, and equipment). Taken together, these initial fees can be viewed as upfront payments that compensate the franchisor for the expenses and effort associated with establishing a new franchised retail outlet (Lafontaine 1992; Sen 1993).

Conventional wisdom among practitioners (for example, Chun 2008; Fell 2011) and extant research (Shane et al 2006) that emphasizes network expansion through the lowering of entry costs for franchisees posits a negative relationship between initial fixed fees and franchisee network size. In contrast, agency theory suggests a positive relationship between these fees and franchisee network size. Wu (1998) states that higher initial fees help a franchisor overcome the agency problems associated with creating a brand name good. A higher initial fixed fee can alleviate the adverse selection problem from the perspective of the franchisor, as it acts as a mechanism for screening and qualifying prospective franchisees (Stump and Heide 1996). In this regard, Dnes (1992) finds that both franchisors and franchisees recognize the screening role played by initial fixed fees stipulated in the franchise contract. Norton (1988), Shane (1996) and Shane (1998) indicate that the size of a franchisee's initial cash investment serves as a signal of franchisee quality - individuals signal their superior capabilities by making an investment where the returns from the investment are dependent on their own abilities to generate revenues.

Higher initial fixed fees may also mitigate the adverse selection problem from the viewpoint of prospective franchisees. Within the range of initial fixed fees observed, a relatively higher fixed fee indicates a greater level of initial franchisor services and investments for new 
franchisees. Guilloux et al (2004) note that prospective franchisees in France ranked startup support from the franchisor as the most important criteria for selecting a franchise system. $\mathrm{Wu}$ (1999) finds support for the view that higher initial fees are positively associated with the upfront investments that franchisors make to help improve the quality of their franchisees. To the extent that prospective franchisees value these services and investments, they will be attracted to join franchise systems with higher initial fixed fees. A higher franchise fee and initial investment may also be regarded by prospective franchisees as signaling favorable private information about the underlying superiority of the franchise concept (Gallini and Lutz 1992). This view is reinforced by Castrogiovanni and Justis (2002), who find a positive association between start-up costs and franchisor growth. To the extent that the ability to charge a price premium to end customers is an indicator of franchise concept quality, Wu (1998) finds support for a positive relationship between initial fixed fees and the quality of the franchise concept.

Relatively higher initial fixed fees may also drive franchisee network size by reducing franchisor and franchisee moral hazard. ${ }^{10} \mathrm{Wu}(1999)$ views high franchise fees and initial investments as bonds that discourage franchisees from free riding. He suggests that high initial fees may encourage franchisees to make the quality investments needed to maintain a franchisor's brand name and successfully differentiate the chain from competitors. Dnes (1992) notes that a franchisee's sunk investments make it more motivated to perform. Lafontaine (1992) and Dnes (1992) suggest a positive relationship between franchise fees and specific investments by the franchisor to open each new outlet. Bercovitz (2000) finds empirical support

\footnotetext{
${ }^{10}$ It can be argued that higher initial fees could lead to greater franchisor moral hazard since the franchisor-specific nature of a franchisee's initial investments exposes it to holdup by the franchisor. Dnes (1992) discounts this argument by noting that franchise contracts are often written to ensure that franchisor appropriation of franchisee assets and investments is restricted to situations of franchisee failure. Indeed, this feature of franchise contracts may instead alleviate the franchisee moral hazard problem by motivating franchisees to succeed in operating their franchised outlets.
} 
for this posited relationship. Specific investments can directly or indirectly (Kacker and $\mathrm{Wu}$ 2013) enhance overall exchange value in the franchisor-franchisee relationship. Moreover, the specific investments described above serve to lock both the franchisor and franchisees into the exchange relationship, thereby lowering the potential gains from moral hazard for either party. This further enhances business format value for the extant exchange partners (as well as prospective franchisees) and, therefore, facilitates the increase of franchisee network size:

H3: $\quad$ The franchise fee and initial investment is positively related to franchisee network size.

\section{Percentage of Owned Outlets}

In addition to determining the fee structure of the franchise contract, a franchisor makes a number of other strategic decisions that affect the size of its franchisee network. Foremost among them is the extent to which the franchisor relies on franchisees to operate outlets in the system, versus owning and managing them itself. Franchising has been viewed as an organizational form that allows a firm to overcome agency costs associated with operating franchisor-owned outlets (Blair and Lafontaine 2005; Brickley and Dark 1987; Combs and Ketchen, Jr. 1999a and 1999b; Combs et al 2004; Combs et al 2011; Lafontaine 1992; Mathewson and Winter 1975; Michael 1996; Rubin 1978).

A number of the agency-theory based arguments used to explain the choice of franchising over operating owned outlets can also be used to support a negative relationship between the percentage of owned outlets and franchisee network size. A franchisee has a stronger residual claim to profits from its outlet operations than does a corporate manager at a franchisor-owned outlet. This suggests relatively lower levels of operator shirking and, therefore, reduced franchisor oversight (Krueger 1991; Norton 1988) at franchised outlets. This implies that, for any given level of monitoring capacity, a franchisor should be able to effectively monitor a larger number of 
franchised outlets than owned outlets. Thus, the lower the percentage of owned outlets, the greater is the number of franchised outlets that can be effectively monitored by the franchisor.

Alternatively, for any given level of monitoring capacity, a franchisor should be able to more effectively monitor a specific number of franchised outlets than the same number of owned outlets, leading to lower ex-post agency costs at the outlet level. Shane (1996) notes that agency problems associated with firm growth are lower when a high percentage of outlets are franchised.

The ownership incentives obtained by franchisees reduce moral hazard associated with suboptimal or misdirected effort when compared to franchisor-owned outlets. The likelihood of franchisee moral hazard is also curtailed by the reduced costs of monitoring franchisees (compared to owned outlets) for the franchisor. This enhances the value of the business format for extant exchange partners, strengthens the competitive position of the franchise system and makes joining it more attractive for prospective franchisees. Therefore,

\section{H4: $\quad$ The percentage of owned outlets is negatively related to franchisee} network size.

\section{Complexity}

Franchisors vary in the complexity of their franchise concepts. Shane $(1998)^{11}$ defines the complexity of a franchisor's business format as a count of the number of different support services that the franchisor contracts to provide to the franchisee as part of the franchising package. The nature and magnitude of these primarily ongoing services can help to differentiate and strengthen the franchise concept and safeguard brand equity. Thus, the ongoing services that a franchisor commits to provide to franchisees can be viewed as a signal of franchisor quality by

\footnotetext{
${ }^{11}$ Shane (1998) draws on agency theory to hypothesize a positive relationship between franchise concept complexity and franchise system failure. He posits that increases in complexity result in higher monitoring costs. Note that Shane (1998) looked at a different pool of franchisors (new franchisors only) and a different performance variable (franchise system failure). It is possible that the complexity of a franchise concept may create monitoring challenges for a new franchisor but that, if it survives and operates for some time, the franchisor will develop the ability to effectively undertake this monitoring
} 
franchisees. Peterson and Dant (1990) found that training provided by the franchisor to franchisees was the top ranked factor influencing the selection of franchise systems by prospective franchisees. Thus, greater complexity alleviates the adverse selection problem from a prospective franchisee's perspective and favorably impacts franchisee network size.

It is likely that a franchisor has to make larger investments to provide the ongoing services associated with more complex franchise concepts. These investments increase the franchisor's stake in the performance of the franchise system. This reduces the likelihood that a franchisor free rides on efforts of franchisees and, thus, lowers franchisor moral hazard.

To the extent that complex franchise concepts involve greater centralization of activities in the franchise system (for example, centralized data processing, centralized purchasing), they are accompanied by lower franchisee moral hazard (Scott 1995). Drawing on the reasoning of Brickley (1999), the greater the volume of services and inputs provided by the franchisor, the fewer are the dimensions on which a franchisee can provide suboptimal or misdirected effort. When a franchisor provides an extensive range of ongoing services to a franchisee, their relationship will be characterized by greater interaction. This, in turn, leads to lower franchisee free riding and improved franchisee sales revenues and performance (Kidwell et al 2007).

The reduction of adverse selection and moral hazard problems in more complex franchise concepts leads to our positing that greater complexity positively impacts franchisee network size:

H5: $\quad$ Greater franchise concept complexity is positively related to franchisee network size.

\section{Concept Development Time}

Lafontaine and Shaw (1998) find the primary driver of franchisor survival to be the number of years that the franchisor has been in business before starting to franchise. They suggest that franchisors that spend more time developing their franchise concept (in terms of 
product or service prototypes, operating procedures and documentation) are more likely to succeed in franchising. Lafontaine (1992) views this period of being in business but not franchising as an indicator of the difficulty and cost of developing the franchise concept while Lafontaine and Shaw (2005) view it as a proxy for the value of a franchisor's brand. When a franchisor spends a greater amount of time developing the business concept before commencing franchising, it is often able to fully dedicate its resources to creating a superior franchise concept. Taken together, these views suggest that the time taken by the franchisor to develop its franchise concept before franchising contributes to its uniqueness and competitive strength. Therefore, prospective franchisees may view this concept development time as a signal of franchisor quality. In this manner, greater concept development time alleviates the adverse selection problem from the viewpoint of prospective franchisees.

When a franchisor spends more time developing its franchise concept prior to franchising, it may make greater investments. It also develops a more valuable brand (Lafontaine and Shaw 2005). Consequently, it is less likely to engage in behavior that jeopardizes these investments and brand name assets. This suggests that longer concept development times lead to lower franchisor moral hazard.

Simultaneously developing and refining a business concept as well as undertaking the recruitment of franchisees and establishing a franchise system can overwhelm a franchisor's managerial capacity. Hence, a relatively large time gap between the initiation of business operations and commencement of franchising by a franchisor ensures that a competitive franchise concept is fully developed prior to initiation of franchising. This enables the franchisor to more clearly and fully define franchisee processes and tasks as well as monitoring procedures, thereby lowering opportunities for franchisee free riding. Additionally, it allows the franchisor to 
fully concentrate on franchisee monitoring once it commences franchising, further lowering the likelihood of franchisee moral hazard.

In sum, greater concept development time should alleviate the adverse selection problem from the viewpoint of prospective franchisees and reduce moral hazard by extant firms in the franchise system. Therefore:

H6: $\quad$ Greater concept development time is positively related to franchisee network size.

\section{Qualification}

Franchisors vary in the requirements and qualifications they impose on prospective franchisees. Bergen et al (1992) posit that prequalifying exchange partners can substantially alleviate adverse selection problems. There is considerable empirical support for this view (Stump and Heide 1996; Wathne and Heide 2004). The use of qualification standards by the franchisor creates a self-selection opportunity for high quality prospective franchisees. Thus, increased qualification requirements reduce the adverse selection problem from the perspective of the franchisor. This is reflected in extant research that shows the use of prior experience as a screening mechanism is negatively related to franchisee failure (Michael and Combs 2008) and new franchise system failure (Shane 1998).

The addition of qualified franchisees that operate within a system with lowered agency costs is likely to increase the value of the franchise concept and make it easier to attract similarly qualified prospective franchisees in the future. Indeed, the presence of these rigorous qualification requirements sends a clear signal to prospective franchisees about the quality of existing franchisees. In this manner, qualification mitigates the adverse selection problem from the perspective of prospective franchisees.

Strict qualification standards may indirectly lower franchisee moral hazard. If an extant 
franchisee recognizes that new franchisees will be carefully screened, it is less likely to expect them to engage in horizontal free riding. This reduces its own incentives to provide poor effort.

The rationales in the preceding paragraphs suggest that rigorous qualification standards directly reduce adverse selection problems and indirectly lower franchisee moral hazard. Thus:

H7: $\quad$ Greater qualification of franchisees is positively related to franchisee network size.

\section{Structural Flexibility}

Structural flexibility allows a firm to better adapt to dynamic environments (Volberda 1996), enabling it to successfully expand over time. One manifestation of this flexibility is the customization of exchange relationships with partners (Doney and Cannon 1997). In franchising, structural flexibility is reflected in initiatives used by a franchisor to customize relationships with franchisees. These include the use of multi-unit franchising and area development agreements, sub-franchising or master franchising, and conversion franchising. We posit that these initiatives aid expansion of franchisee networks by lowering agency costs.

Multi-unit franchising (whether through area development agreements or sequential expansion) can facilitate the development of large franchisee networks by reducing adverse selection problems from the perspective of the franchisor. Kaufmann and Dant (1996) find that the use of multi-unit franchising by a franchisor enables it to draw high quality, well-resourced franchisees into its system. Multi-unit franchising facilitates franchisee self-selection, in terms of attracting franchisees that have the ability to successfully operate multiple franchised outlets.

Multi-unit franchising allows franchisees to internalize externalities and reduce spillover effects, limiting horizontal free riding by other franchisees (Brickley 1999). Perryman and Combs (2012) find that outlets operated by multi-unit franchisees are located close to each other as well as to the multi-unit franchisee's headquarters. Consequently, the likelihood of horizontal 
free riding by another franchisee is reduced and the multi-unit franchisee is easily able to monitor operations at its various outlets. Since a franchisee with an area development agreement has the sole authority to develop outlets within its designated territory, it faces reduced encroachment risk and is more willing to make value-enhancing specific investments (Azoulay and Shane 2001). Bercovitz (2002) finds that multi-unit franchising enhances the downstream rent potential for franchisees, thereby creating the front-end of self-enforcing agreements and lowering the potential for franchisee moral hazard (Klein 1980). The potential to add new outlets acts as a strong incentive to franchisees to preserve standards, safeguard the franchisor's brand name at their existing outlets and refrain from suboptimal or misdirected effort (Bradach 1997). Gillis et al (2011) view multi-unit franchising through the incentive-based lens of tournament theory and conclude that new outlets are prizes given out to the best performing extant franchisees. Taken together, these arguments indicate that multi-unit franchising enhances franchisee incentives and, thereby, lowers the likelihood of franchisee moral hazard.

Under master franchising (also known as sub-franchising), a franchisor does not sell franchises directly to outlet operators. Instead, it sells territories to a master franchisee (subfranchisor) who then sells franchises to individual outlet operators. The master franchisee performs key functions on behalf of the franchisor (including the selection and monitoring of individual franchisees) and is associated with higher system growth rates (Kaufmann and Kim 1995). Although master franchising results in an additional layer of hierarchy, it also involves delegation of regional expansion decisions to an entity more familiar with the region (Justis and Judd 1986). The regional expertise and knowledge possessed by the master franchisee enables it to more effectively screen prospective franchisees, thus lowering the adverse selection problem from the perspective of the franchisor. 
A master franchisee's familiarity with its region of operation makes it more effective in monitoring franchisees. This is particularly so when a franchisor, faced with the "entrepreneurial capacity problem" (Norton 1988), is unable to fully monitor franchisees on its own. Franchisee monitoring by the master franchisee, particularly when coupled with an additional level of individual outlet monitoring (by the franchisor), reduces franchisee moral hazard. ${ }^{12}$

Conversion franchising involves the recruitment of franchisees from other chains and franchise systems. Franchisors who use conversion franchising acquire experienced franchisees that require lower training costs (Hoffman and Preble 2003). This mitigates the adverse selection problem from the perspective of the franchisor and facilitates franchisee network expansion Taken together, the different structural flexibility initiatives discussed above (multi-unit franchising, master franchising and conversion franchising) positively impact franchisee network size by reducing adverse selection (from the perspective of the franchisor) and lowering franchisee moral hazard. This leads to:

H8: $\quad$ Greater structural flexibility is positively related to franchisee network size. The agency cost reducing effects of the different franchisor strategies considered by us are summarized in Table 2.

\section{Insert Table 2 about here}

\footnotetext{
${ }^{12}$ There are arguments in the franchising literature for positive effects of the use of master franchising on franchisee moral hazard. For example, Shane (1998) posits and finds a positive relationship between the use of master franchising and franchise system failure. However, this view must be considered in the context of the sample of new franchisors studied by him. Shane (1998) notes that the use of master franchising requires codification of enforcement behavior and that this enforcement behavior must either be specified at the time of contracting or be foregone. This is particularly challenging for a new franchisor that is likely to be unable to foresee all possible mechanisms for franchisee shirking. We note, again, that we differ from Shane (1998) in terms of the types of franchisors (new franchisors only vs. franchisors of all ages) and organizational performance measures (franchise system failure vs. franchisee network size) studied. In our assessment, if a franchisor survives and operates for some time (and, in the process, acquires knowledge about different forms of franchisee shirking), it may be in a better position to codify enforcement behavior in master franchise agreements and realize the franchisee moral hazard reducing benefits of master franchising.
} 


\section{Control Variables}

We also investigate the effects of four control variables on franchisee network size. Two of these variables (age and size of the organization) are commonly used in interorganizational research for control purposes, since they are expected to impact various theoretically vested relationships in a systematic fashion. The third control variable, the percentage of units in the U.S., is unique to the context at hand - franchising has its genesis in the U.S., and therefore its domestic percentage may have some systematic effects on franchisee network size. Our final control variable is lagged - franchisee network size in the previous time period.

\section{DATA}

We test our hypotheses using secondary data drawn from the widely used Bond's Franchise Guides that have been published from 1985 onwards. ${ }^{13}$ In contrast to Shane et al (2006) and Kosová and Lafontaine (2010), we chose to use a smaller balanced panel rather than a larger unbalanced panel. Our choice was guided by concerns about the time series aspects of the data analysis. A balanced panel is necessary to test for a common panel unit root, to facilitate the assessment of nonstationarity and panel cointegration in the data. This test, which enhances the rigor of our empirical analyses, would not be possible had we used an unbalanced panel.

A balanced panel requires the presence of data for every year for each firm in the panel. Thus, there is a tradeoff involving the number of years of data and the list-wise sample size across those years for the variables of interest. We ultimately settled on the years 1995 through 2004 (that is, nine years) with an annual sample size of N=76. Any franchisor listed in Bond's for all of these nine years was included in the balanced panel. Our econometric analysis is based on panel data with $\mathrm{N}=684$ (9 years $\mathrm{x} 76$ ) cases. In our assessment, this panel has sufficient

\footnotetext{
${ }^{13}$ Note that, as of 2005, no Guides were published for the years 1986, 1987, 1990 and 2000.
} 
breadth (in terms of the number of franchisors) and length (in terms of years of data) for our dynamic panel model estimation. The 76 franchisors in our sample cover 23 of the 50 industry sectors contained in Bond's Franchise Guide for $1994 .{ }^{14}$ If we had chosen a larger number of years for the balanced panel, there would have been considerable attrition in the number of franchisors in the panel. If we had opted for a larger number of franchisors in the balanced panel, we would have had to reduce the number of years of data used, potentially inhibiting insights from the investigation of temporal variations in the panel.

We present details of the operationalizations of our variables and constructs in Table 3.

\section{Insert Table 3 about here}

Our operationalizations are largely either definitional (for example, Franchisee Network Size, Royalty Rate, Advertising Fee, Franchise Fee and Initial Investment, Percentage of Owned Outlets) or based on operationalizations in extant research (that is, Complexity, Concept Development Time, Qualification). Our operationalization of Structural Flexibility is based on conceptual definitions of the construct in the extant literature.

\section{ANALYSES AND RESULTS}

As when doing traditional time series analysis, we first test for nonstationarity (that is, we test for a panel unit root ${ }^{15}$. If we find that the variables in the panel are nonstationary, we need

\footnotetext{
${ }^{14}$ Note that although our panel data set covers a number of industries, our fixed effects estimation approach (that accounts for unobserved heterogeneity) alleviates the need for industry specific control variables in our model.

${ }^{15}$ Econometric analysis has traditionally consisted of cross-sectional analysis, time series analysis, or panel data analysis with a small and fixed time series dimension. There has been a growing interest in studying cross-sectional data over time, entailing the use of panel data models with both a large number of cross-sectional units and a large number of time series observations. When working with panel data that has a large time series dimension, we gain additional power over traditional time series analysis from the increased observations in the cross-section dimension but we must deal with potential nonstationarity in the time series dimension of the data. Recent research has improved our ability to analyze nonstationarity, cointegration and the spurious regression problem in panel data. These issues have been examined extensively in pure time series (Engle and Granger 1987), but only recently have they been studied in detail in panel data models. These new panel data methods are extensions of the traditional
} 
to ensure that we avoid the spurious regression problem. To do this, we test for panel

cointegration. This means that we test for a long-run relationship between the variables that is stationary even though the data series themselves are nonstationary. If the tests indicate a cointegration relationship between the nonstationary variables, we proceed with estimating this long-run relationship using appropriate panel estimation techniques. If the tests indicate that there is no cointegration relationship, then there is no long-run equilibrium to estimate. Note that the tests for a common unit root and panel cointegration require balanced panels.

In our cointegration analysis, all panel estimations and inferences were carried out using EViews 6.0. In order to consider the issue of panel cointegration, we first test for a panel unit root in each of the variables. Descriptive statistics and correlation coefficients are contained in Table 4. Results for the panel unit root tests are presented in Table 5.

\section{Insert Tables 4 and 5 about here}

We use the panel unit root tests suggested by Levin et al (2002), with intercept terms in the test equation. When testing for a panel unit root, the null hypothesis is that there is a panel unit root, that is, the data series is nonstationary. The results of the Levin et al (2002) unit root test with individual effects included in the test equation indicate that the null hypothesis of a common panel unit root can be rejected for every variable. In other words, all variables can be treated as stationary. If the data were nonstationary, the t-statistics would diverge unless there was a cointegrating relationship. Since all variables appear not to have a panel unit root, there is

time series methodology, using the additional information gained from the cross-section dimension of the panel. Testing for unit roots in pure time series studies is common practice among applied researchers. For the nontechnical reader, it is important to point out that the terms unit root, nonstationarity, and random walk (process) mean the same thing and can be used interchangeably. These terms mean that the data series under consideration can be written as $\mathrm{y}_{\mathrm{t}}=\mathrm{y}_{\mathrm{t}-1}+\varepsilon_{\mathrm{t}}$, for the case of a random walk without drift or $\mathrm{y}_{\mathrm{t}}=\alpha+\mathrm{y}_{\mathrm{t}-1}+\varepsilon_{\mathrm{t}}$, for the case of a random walk with drift (constant term) where $y_{t}$ is the data series and $\varepsilon_{t}$ is white noise (Hamilton 1994). 
no spurious regression problem and the t-statistics using traditional estimation will be reliable. Thus, we continue to the estimation stage without having to test for panel cointegration. In estimating our model, it is important to control for unobserved heterogeneity to rule out the confounding effects of unobserved characteristics on which franchisors may vary (Gonzalez-Diaz and Solis-Rodriguez 2012, Shane et al 2006). Failure to control for this unobserved heterogeneity results in biased regression estimates (Heckman 1981). These estimates may also be rendered biased by endogeneity problems with some of our regressors (Gonzalez-Diaz and Solis-Rodriguez 2012, Shane et al 2006). In keeping with the extant literature (for example, Shane et al 2006), we considered royalty rate, advertising fee, franchise fee and initial investment, and percentage of owned outlets as endogenous variables. To account for endogeneity, we used instrumental variables that would satisfy two conditions: (i) instrument relevance - the instrument must be correlated with the endogenous variable and (ii) instrument exogeneity - the instrument must not be correlated with the disturbance. We used instruments that included lags of endogenous variables, all exogenous variables, and dynamic period-specific (predetermined) instruments. The use of lagged independent variables to account for endogeneity is also in keeping with practices widely adopted in extant franchising research (Combs et al 2009, Gonzalez-Diaz and Solis-Rodriguez 2012, Lafontaine 1992, Mitsuhashi et al 2008, and Shane et al 2006). Additionally, these instruments are required, by the dynamic panel GMM estimation methods we use, to identify and estimate the model. Gonzalez-Diaz and SolisRodriguez (2012) note that Arellano and Bond (1991) recommend that lagged values of endogenous independent variables in the model should be used as instruments.

We estimate our model using Arellano and Bover dynamic panel GMM estimation (Arellano and Bover 1995). In the Arellano and Bover method, both the weight matrix and 
coefficients are updated (that is, re-estimated iteratively) until convergence. This approach often yields better finite sample properties of the estimators than other approaches such as the Arellano and Bond (1991) two step method (where the GMM weight matrix is updated once and the final coefficients are then estimated) and the two stage least squares fixed effects approach used by Shane et al (2006). The Arellano and Bover approach accounts for unobserved heterogeneity and endogeneity in the data. We use orthogonal deviations to remove the fixed effects terms and White period robust SEs that are robust to innovations that have time series correlation structure that varies by cross-section.

Our estimation results (and hypothesized effects) are summarized in Table 6.

\section{Insert Table 6 about here}

The descriptive statistics in Table 4 reveal relatively high correlations involving three pairs of independent and control variables: 0.94 between Concept Development Time and Structural Flexibility; 0.82 between Concept Development Time and Percentage of Outlets in the US (a control variable); and 0.77 between Structural Flexibility and Percentage of Outlets in the US. High pairwise correlations are only a sign of potential multicollinearity. However, for Concept Development Time and Structural Flexibility, we believe that multicollinearity is not a problem. Note, from Table 6 , that the estimated coefficients on each are highly significant. If multicollinearity between these variables was a serious problem, the standard errors would be inflated and the estimated coefficients would not be statistically significant.

As a further test of the robustness of our model, we re-estimated it twice. In the first reestimation, we dropped Structural Flexibility as a predictor (keeping Concept Development Time and the control variable - Percentage of Outlets in the US - in the model). In the second reestimation, we dropped Concept Development Time as a predictor (keeping Structural Flexibility 
and the control variable - Percentage of Outlets in the US - in the model). For both estimations, we observed that the effects for the independent variables that remained in the model were statistically significant and at levels almost identical to those observed for the full model. ${ }^{16}$

In assessing potential misspecification of the model, we use the Sargan statistic (Sargan 1958) to test the null hypothesis that the over-identifying restrictions are valid. The nonsignificance of the Sargan test is a necessary condition for helping to establish the validity of our instruments. The results do not reject the null hypothesis and support the validity of our instruments.

The coefficients for the individual predictors (in Table 6) can be construed in a manner similar to interpreting OLS coefficients, in terms of the variable coefficient being related to the size of the underlying latent variable. In other words, the absolute value of the coefficient depends on the units in which the predictor is measured. Therefore, for example, the coefficient for Franchise Fee and Initial Investments is low even though the effect is significant - this is because the variable is measured in $\$$ and the mean for this variable is $\$ 224,789.8$.

The coefficients on the independent variables are short-run multipliers, i.e., the impact of a change in $\mathrm{X}$ on $\mathrm{Y}$ in this period. The coefficient on the lagged value of network size can be used to calculate the long-run multipliers for each variable, i.e., total impact over time of a change in $\mathrm{X}$ on $\mathrm{Y}$. The long-run multiplier is the estimated coefficient on $\mathrm{X}$ multiplied by $\{1 /(1$ - estimated coefficient on lagged dependent variable $)\}$, i.e., $\beta \gamma\left(1 /\left(1-\delta^{\wedge}\right)\right)$.

For the individual predictors, we find statistically significant support for seven of our eight hypotheses - H1, H2, H4, H5, H6, H7, and H8 are supported by the estimation results. A higher Royalty Rate, higher Advertising Fee, smaller Percentage of Owned Outlets, greater

\footnotetext{
${ }^{16}$ In the interests of brevity, we have not included the re-estimation results in the paper. These results can be requested from the authors.
} 
Complexity, longer Concept Development Time, greater use of Qualification procedures, and more Structural Flexibility are associated with larger franchisee network size. For H3, the results are the opposite of what we predicted - the franchise fee and initial investment are significantly negatively related to franchisee network size. One potential explanation for this is that franchise chains with much larger physical retail outlets are likely to have higher initial investment fees attached to them. The large size of these outlets may create a bigger minimum efficient scale for their operation, leading to a lower franchisee network size. ${ }^{17}$

Effects for three control variables (Franchisor Age, Franchisor Organization Size and Franchisee Network Size in Previous Year) are also significant. As expected, there is a strong positive relationship between the dependent variable and the franchisee network size in the previous time period. In terms of direction of effects for the control variables, there were two surprises: Franchisor Age had a significant negative effect and the Percentage of Outlets in the U.S. had a nonsignificant effect on franchisee network size.

In sum, we find that for most of the predictors, the agency theory-based rationales for their effects on franchisee network size are supported. It is worth noting that many of the variables that had previously been ignored in explaining franchise or total system size (for example, Complexity, Concept Development Time, Qualification, and Structural Flexibility) are found to have a statistically significant effect on franchisee network size.

These results, taken together, largely negate the conventional wisdom among practitioners that key drivers of a franchisor's franchisee network size are strategies that simply

\footnotetext{
${ }^{17} \mathrm{We}$ are grateful to an anonymous reviewer for another potential explanation for the significant negative relationship between the initial fixed fees and franchisee network size. This explanation revolves around the chronological context of our data. Our data set covers the period 1995-2004. This was a time during which property prices experienced substantial appreciation in the U.S. and represented an attractive asset class for investments. The return on investment offered by the franchises with high initial fixed fees may have been less attractive compared with property investment alternatives. At lower levels of initial fixed fees, prospective franchisees may not have had similarly attractive property investment alternatives available to them.
} 
lower entry and ongoing costs and barriers for prospective franchisees. It is important to note that the estimation results do not rule out the existence of the effects proffered by this perspective. Rather, these effects may be weaker than those occurring in the opposing direction and supported by our agency theory-based reasoning. Indeed, it is the agency cost reducing properties of the franchisor strategies examined here that primarily drive franchisee network size.

\section{DISCUSSION}

Our findings generate valuable insights for franchising practice. What should a franchisor do to have a large franchisee network? It can expand franchisee network size by taking time to develop, refine and test its business format prior to franchising it. This results in a stronger franchise concept as well as more developed franchisor capabilities for monitoring and supporting franchisees. A relatively long lag between founding the business and starting franchising can interpreted as a signal of franchisor quality by prospective franchisees and motivate more of them to join the franchisee network. Expansion of the franchisee network is also facilitated when franchisor quality is signaled through relatively higher royalty rates and advertising fees. These ongoing fees (as well as franchise concept complexity) communicate the franchisor's commitment to provide ongoing services and advertising support to franchisees. The use of rigorous criteria for qualifying franchisees alleviates concerns of prospective franchisees that other franchisees will abuse their membership in the system. Finally, franchisee network size is increased when the franchisor limits its reliance on franchisor-owned outlets and embraces structural flexibility in designing exchange with franchisees. A number of these strategies further facilitate franchisee network expansion by lowering free riding by the franchisor and extant franchisees in the network. 
Our results counter the conventional wisdom among practitioners that a franchisor can rapidly grow by reducing entry and continuing costs for prospective franchisees via minimal franchisee qualification requirements and low ongoing royalty and advertising fees. Although these actions may result in an expanded pool of prospective franchisees interested in joining the franchise system, they do not translate into greater franchisee network size. By maintaining relatively higher royalty and advertising fees as well as imposing rigorous qualification standards, a franchisor may have a smaller overall pool of interested prospective franchisees, but these franchisees are likely to be of higher quality and in a better position to contribute to brand equity and strengthen system reputation. The higher ongoing fees also provide appropriate means and incentives to the franchisor to maintain and enhance the franchise concept and brand equity. Thus, these policy decisions allow the franchisor to operate and expand the franchisee network effectively, and continue to attract high quality franchisees.

Limitations of our research include the range of franchisors to which our findings apply, the franchisor decision variables we consider, and some of our construct operationalizations. Business format franchisors that use a flat dollar royalty (albeit a rare occurrence) are outside the scope of our theoretical model. Additionally, our findings do not extend to product-name franchisors (that do not charge royalties but extract rents from franchisees through markups on products supplied to them). One limitation of the choice of franchisee network size as a measure of performance is that it may be influenced by variables not included in our model - for example, the personal values and objectives of franchisors, the amount of money spent on franchise marketing to prospective franchisees and corporate strategy shifts that emphasize franchise buybacks or refranchising. Our estimation approach includes firm fixed effects and, therefore, accounts for many of these sources of unobserved heterogeneity. However, an understanding of 
the nature and magnitude of the effects of these variables may be of interest to franchising practitioners. Finally, some of our predictors (for example, Complexity, Qualification and Structural Flexibility) are operationalized using count-based measures. Such count-based measures have been frequently used in franchising research (for example, Shane 1998). However, in using such measures, researchers make an implicit assumption that a larger count of items for a construct is equivalent to a higher magnitude of that construct. In addition, this approach indicates that two firms are viewed to have the same magnitude of a construct if they have the same count of items for that construct, even if the specific items differ across them.

We make a number of theoretical and methodological contributions to research in franchising. Many researchers have studied the factors that influence the size and growth of a franchisor's overall system of franchised and company owned-outlets. However, to our knowledge, a specific and focused investigation of the drivers of the size of a franchisor's franchisee network has never been undertaken. The importance of such an investigation is underscored by the fact that factors that influence the size of the total network and of the franchisee network may differ and should be disentangled. Moreover, a number of franchisor strategic decisions are specifically designed to impact franchised outlets and the effectiveness of these decisions should be measured with the yardstick of franchisee network size rather than total network size. Therefore, we make an important contribution to the franchising literature by specifically investigating the drivers of a franchisor's franchisee network size.

Agency theory has been previously applied to understand key franchisor decisions such as whether it should rely on franchising, the extent to which it should do so, and the design of the franchise contract. We draw on this theory to explain variations in franchisee network size. We find that this perspective provides a better explanation for franchisee network size than the 
financial cost-based conventional wisdom. Much of the extant agency theory research in franchising has focused on studying either adverse selection (concerning prospective franchisees) or moral hazard (revolving around extant franchisees) problems. We contribute to this stream of research by jointly studying the adverse selection and moral hazard problems faced by franchisors. We describe how the same set of franchisor strategies have ramifications for both the adverse selection and moral hazard problems in the system and explain how franchisor strategies designed to directly impact one problem may also indirectly affect the other.

Our contributions on the empirical front include the use of a broad group of franchisors and franchisor decision variables as well as econometric analysis that checks for nonstationarity and accounts for endogeneity and unobserved heterogeneity. We provide more exhaustive coverage of the franchisor universe by including franchisors of all ages and size. Our sample comprises of public and privately held franchisors from a wide range of industries, in keeping with the calls for such samples from Gillis and Castrogiovanni (2012). We use a richer set of explanatory variables than any previous studies of franchise or total system growth. This decision is justified by the empirical results that show a statistically significant effect on franchisee network size of many franchisor strategies (for example, Concept Development Time, Complexity, Qualification and Structural Flexibility) that had not been considered in previous research on drivers of network size. Finally, we estimate our dynamic panel data models with a concern for potential nonstationarity, endogeneity and unobserved heterogeneity. To our knowledge, no previous empirical studies of network size and performance in franchising have done this. Even though we ultimately find no evidence of nonstationarity in our data, checking for it prior to model estimation is important as it helps safeguard against drawing inferences from potentially spurious estimates. We use Arellano-Bover dynamic panel GMM estimation (Arellano and Bover 1995) 
with White period robust SEs that are robust to innovations that have time series correlation structure that varies by cross-section. In our view, this estimation method enhances the rigor observed in previous panel data studies in franchising (for example, Shane et al 2006).

Given the relative paucity of research on franchisee network size and growth, this is a fertile area for future research. While we focus on using agency theory to explain variations in franchisee network size, future research could combine it with other institutional economics and organization theory perspectives to refine explanatory insights. This would echo the integrative approach of Combs and Ketchen Jr., (1999a, 1999b), who draw on agency and resource acquisition theories to jointly explain the extent to which a franchisor uses franchising. Future research could also aim to understand how the importance of different drivers of franchisee network size changes over the lifecycle of a franchise system. The role of the broader economic context (in terms of the health of the overall economy and its implications for alternative investment opportunities for prospective franchisees) could be considered by examining the posited relationships in different business cycles. Additionally, there is considerable scope to study other dimensions and measures of network size and growth - for example, the question of why some franchisors are able to successfully expand across a wide geographic area while others are limited to succeeding by remaining in focused geographic regions. This issue is particularly germane today as franchisors expand rapidly within and across countries. Finally, it is possible that the drivers of franchisee network size vary across countries - future research could investigate how actions needed to expand franchisee networks outside the U.S. may be different from those seen to drive franchise network size within the U.S. 


\section{REFERENCES}

Arellano, Manuel, and Stephen R. Bond (1991), "Some Tests Of Specification for Panel Data: Monte Carlo Evidence and an Application to Employment Equations," Review of Economic Studies, 58, 277-297.

and Olympia Bover (1995), "Another Look at the Instrumental Variables Estimation of Error-component Models," Journal of Econometrics, 68, 29-51.

Arrow, Kenneth (1985), "The Economics of Agency," Principals and Agents: The Structure of Business, Boston.

Azoulay, Pierre and Scott Shane (2001), "Entrepreneurs, Contracts, and the Failure of Young Firms," Management Science, 47, 337-358.

Bercovitz, Janet E. L. (2000), “An Analysis of the Contract Provisions in Business-Format Franchise Agreements," Working Paper.

(2002), “The Option to Expand: The Use of Multi-Unit Opportunities to Support SelfEnforcing Agreements in Franchise Relationships," Academy of Management Proceedings, Y1Y6.

Bergen, Mark, Shantanu Dutta and Orville C. Walker, Jr. (1992), “Agency Relationships in Marketing: A Review of the Implications and Applications of Agency and Related Theories," Journal of Marketing, Vol. 56, No. 3. (July), 1-24.

Bhattacharyya, Sugato, and Francine Lafontaine (1995), "Double-Sided Moral Hazard and the Nature of Share Contracts," The RAND Journal of Economics, 761-781.

Blair, Roger D. and Francine Lafontaine (2005), The Economics of Franchising, Cambridge: Cambridge University Press.

Bradach, Jeffrey L. (1997), "Using the Plural Form in the Management Of Restaurant Chains," Administrative Science Quarterly, 42, 276-303.

Brickley, James A. and Frederick H. Dark (1987), "The Choice of Organizational Form: The Case of Franchising," Journal of Financial Economics, 18: 401-420.

(1999), "Incentive Conflicts and Contractual Restraints: Evidence from

Franchising," Journal of Law and Economics, 42, 745-774.

(2002), "Royalty rates and upfront fees in share contracts: evidence from franchising," Journal of Law, Economics, and Organization, 18(2), 511-535.

Castrogiovanni, Gary and Robert Justis (2002), "Strategic and contextual influences on firm growth: An empirical study of franchisors," Journal of Small Business Management, 40, 98-108. 
Chun, Janean (2008), “Good Time to Get a Deal on a Franchise," Entrepreneur, December 3.

Combs, James G., and David J. Ketchen Jr., (1999a), "Explaining interfirm cooperation and performance: Toward a reconciliation of predictions from the resource-based view and organizational economics," Strategic Management Journal, 20(9), 867-888.

and (1999b), "Can Capital Scarcity Help Agency Theory Explain Franchising: Revisiting the Capital Scarcity Hypothesis," Academy of Management Journal, 42(2), 196-207.

and (2003), "Why do firms use franchising as an entrepreneurial strategy?: A meta-analysis," Journal of Management, 29, 443-465.

, Christopher L. Shook and Jeremy C. Short (2011), "Antecedents and Consequences of Franchising: Past Accomplishments and Future Challenges," Journal of Management, 37(1), 99-126.

, Steven C. Michael, and Gary J. Castrogiovanni (2004), "Franchising: a review and avenues to greater theoretical diversity," Journal of Management, 30(6), 907-931.

, and (2009), "Institutional influences on the choice of organizational form: The case of franchising," Journal of Management, 35(5), 1268-1290.

Dant, Rajiv P. and Paul D. Berger (1996), "Modeling Cooperative Advertising Decisions in Franchising," Journal of the Operational Research Society, 47, 1120-1136.

, Marko Grünhagen and Josef Windsperger (2011), "Franchising Research Frontiers for the Twenty-First Century," Journal of Retailing, 87(3), 253-268.

, Manish Kacker, Anne T. Coughlan and Jamie Emerson (2007), 'A Cointegration Analysis of the Correlates of Performance in Franchised Channels of Distribution,' Economics and Management of Networks: Franchising Networks, Cooperatives, Joint Ventures and Alliances. Eds. Gerard Cliquet et. al., Springer, 169-189.

, Audhesh K. Paswan and Patrick J. Kaufmann (1996), "What We Know about Ownership Redirection in Franchising: A Meta-Analysis," Journal of Retailing, 72 (4), 429-444.

Dnes, Antony W. (1992), “Unfair' Contractual Practices and Hostages in Franchise Contracts,” Journal of Institutional and Theoretical Economics, 484-504.

Doney, Patricia M. and Joseph P. Cannon (1997), "An Examination of the Nature of Trust in Buyer-Seller Relationships," Journal of Marketing, 61 (April), 35-51.

Eisenhardt, Kathleen (1989), "Agency theory: An assessment and review”, Academy of Management Review, 14 (1), 57-74. 
Engle, R. \& Granger, C. (1987), “Cointegration and Error Correction: Representation, Estimation and Testing," Econometrica, 55, 251-276

Fell, Jason (2011), "Franchise Slashes Fees to Spur Jobs,” Entrepreneur, July 11.

Gallini, Nancy T and Nancy A. Lutz (1992), "Dual Distribution and Royalty Fees in Franchising," Journal of Law, Economics and Organization, 8(3), 471-501.

Gillis, William and Gary J. Castrogiovanni (2012), "The franchising business model: an entrepreneurial growth alternative," International Entrepreneurship and Management Journal, 8(1), 75-98.

, Ellen McEwan, T. Russell Crook, and Steven C. Michael (2011), "Using Tournaments to Reduce Agency Problems: The Case Of Franchising," Entrepreneurship Theory and Practice, $35,427-447$.

Gonzalez-Diaz, Manuel and Vanesa Solis-Rodriguez (2012), "Why Do Entrepreneurs Use Franchising as a Financial Tool? An Agency Explanation," Journal of Business Venturing, May, 325-341.

Grünhagen, Marko and Michael J. Dorsch (2003), "Does the Franchisor Provide Value to Franchisees? Past, Current and Future Value Assessments of Two Franchisee Types," Journal of Small Business Management, 41(4), 366-384.

Guilloux, Véronique, Claire Gauzente, Michel Kalika, and Nathalie Dubost (2004) "How France's Potential Franchisees Reach Their Decisions: A Comparison with Franchisers' Perceptions," Journal of Small Business Management, 42(2), 218-224.

Hamilton, James D. (1994), Time Series Analysis, Princeton, NJ: Princeton University Press.

Heckman, J. (1981), "Heterogeneity and state dependence," in: Rosen, S. (Ed.), Studies in Labor Markets, University of Chicago Press, Chicago, 91-139.

Hoffman, Richard C. and John F. Preble (2003), "Convert to Compete: Competitive Advantage through Conversion Franchising," Journal of Small Business Management, 41 (2), 187-204.

Justis, Robert.T. and Richard Judd (1986), "Master Franchising: A New Look," Journal of Small Business Management, 24, 16-21.

Kacker, Manish and Ruhai Wu (2013), "Specific Investments in Franchisor-Franchisee Relationships: A Model,” Journal of Marketing Channels, 20:1-2, 120-140.

Kalnins, Arturs (2004), "An Empirical Analysis of Territorial Encroachment in Franchised and Company-owned Branded Chains,” Marketing Science, 23(4), 476-489. 
Kaufmann, Patrick J. and John Stanworth (1995), “The Decision to Purchase a Franchise: A Study of Prospective Franchisees," Journal of Small Business Management, October, 22-33.

and Sang Hyeon Kim (1995), "Master franchising and system growth rates," Journal of Marketing Channels, 4, no. 1-2, 49-64.

and Rajiv P. Dant (1996), "Multi-Unit Franchising: Growth and Management Issues," Journal of Business Venturing, 11 (5), 343-358.

Kidwell, Roland, Arne Nygaard and Ragnhild Silkoset (2007), "Antecedents and Effects of Free Riding in the Franchisor-Franchisee Relationship," Journal of Business Venturing, 22, 522-544.

Klein, Benjamin (1980), “Transaction Cost Determinants of 'Unfair' Contractual Arrangements," American Economic Review, 70, 356-362.

Kling, Gerhard, Abby Ghobadian and Nicholas O'Regan (2009), “Organic Growth and Shareholder Value: A Case Study of the Insurance Industry," International Journal of Research in Marketing, 28(4), 276-283.

Kosová, Renáta and Francine Lafontaine (2010), "Survival and Growth in Retail and Service Industries: Evidence from Franchised Chain," The Journal of Industrial Economics, LVIII (3), 542-578.

Krueger, Alan B. (1991), "Ownership, agency, and wages: An examination of franchising in the fast food industry," The Quarterly Journal of Economics, 106(1), 75-101.

Lal, Rajiv, 1990. "Improving Channel Coordination Through Franchising," Marketing Science, 9, 299-318.

Lafontaine, Francine (1992), “Agency theory and franchising: Some empirical results," RAND Journal of Economics, 23, 263-283.

(1993), 'Contractual arrangements as signaling devices: Evidence from franchising,' Journal of Law, Economics, and Organization, 9, pp. 256-289.

and Kathryn L. Shaw (1998), "Franchising Growth and Franchisor Entry and Exit in the U.S. Market: Myth and Reality," Journal of Business Venturing, 13(2), 95-112.

and (2005), "Targeting managerial control: evidence from franchising," RAND Journal of Economics, 131-150.

and Margaret E. Slade (1997), "Retail contracting: Theory and practice," The Journal of Industrial Economics, 45.1, 1-25.

Levin, Andrew, Chien-Fu Lin and Chia-Shang James Chu (2002), "Unit root tests in panel data: asymptotic and finite-sample properties," Journal of Econometrics, 108, 1-24. 
Madanoglu, Melih, Kyuho Lee and Gary J. Castrogiovanni (2011), "Franchising and firm financial performance among U.S. restaurants," Journal of Retailing, 87(3), 406-417.

Mathewson, G. Frank and Ralph A. Winter (1985), "The Economics of Franchise Contracts," Journal of Law and Economics, 28(0ctober), 503-526.

Michael, Steven C. (1996), "To franchise or not to franchise: An analysis of decision rights and organizational form shares," Journal of Business Venturing, 11, 57-71.

(2000), "The effect of organizational form on quality: the case of franchising," Journal of Economic Behavior \& Organization, 43(3), 295-318.

(2002), “Can a franchise chain coordinate?” Journal of Business Venturing, 17(4), 325-341.

(2003), "Determinants of franchising across nations," Management International Review, 43, 267-290.

(2009), "Entrepreneurial signaling to attract resources: the case of franchising,"

Managerial and Decision Economics, 30 ( 6), pp. 405-422.

and James G. Combs (2008), "Entrepreneurial Failure: The Case of Franchisees," Journal of Small Business Management, 46(1), 73-90.

Mitsuhashi, Hitoshi, Scott Shane and Wesley D. Sine (2008), "Organization Governance Form in Franchising: Efficient Contracting or Organizational Momentum?” Strategic Management Journal, 29 (10), 1127-36.

Norton, Seth W (1988), "Franchising, Brand Name Capital and the Entrepreneurial Capacity Problem," Strategic Management Journal, 9, 105-114.

Perrigot, Rozenn (2004), "Le Choix Des Reseaux De Points De Vente: Une approche par l'écologie des populations et les analyses de survie," Doctoral thesis, University of Rennes.

Perryman, Alexa A. and James G. Combs (2012), "Who should own it? An agency-based explanation for multi-outlet ownership and co-location in plural form franchising," Strategic Management Journal, 33(4), 368-386.

Peterson, Alden and Rajiv P. Dant (1990), "Perceived advantages of the franchise option from the franchisee perspective: empirical insights from a service franchise," Journal of Small Business Management, 28(3), 46-61.

Price Waterhouse Coopers (2008), Economic Impact of Franchised Businesses Vol II: Results for 2005, International Franchise Association Educational Foundation.

Rubin, Paul H. (1978), "The Theory of the Firm and the Structure of the Franchise Contract," Journal of Law and Economics, 21, 223-233. 
Sargan, John D. (1958), “The Estimation of Economic Relationships Using Instrumental Variables," Econometrica, 26, 393-415.

Scott Jr, Frank A. (1995), "Franchising vs. company ownership as a decision variable of the firm," Review of Industrial Organization, 10(1), 69-81.

Sen, Kabir C. (1993), "The use of initial fees and royalties in business-format franchising," Managerial and Decision Economics, 14 (2), 175-190.

(1998), "The Use of Franchising as a Growth Strategy by US Restaurant Franchisors," Journal of Consumer Marketing, 15 (4), 397-407.

Shane, Scott (1996), "Hybrid Organizational Arrangements and their Implications for Firm Growth and Survival: A Study of New Franchisors," Academy of Management Journal, 39, 216234. $\overline{697-707 .}$

(1998), “Making New Franchise Systems Work," Strategic Management Journal, 19,

,Venkatesh Shankar and Ashwin Aravindakshan (2006), "The Effects of New Franchisor Partnering Strategies on Franchise System Size,” Management Science, 52(5), 773-787.

Spence, Michael (1973), “Job Market Signaling,” Quarterly Journal of Economics,87(3),355-74.

Srinivasan, Raji (2006), "Dual Distribution and Intangible Firm Value: Franchising in Restaurant Chains," Journal of Marketing, 70 (July), 120-135.

Stanworth, John (1996), "Dispelling the Myths Surrounding Franchise Failure Rates: Some Recent Evidence from Britain,” Franchising Research: An International Journal, 1, 25-28.

Stump, Rodney L. and Jan B. Heide (1996), "Controlling Supplier Opportunism in Industrial Relationships," Journal of Marketing Research, 33 (November), 431-41.

U.S. Department of Commerce (1987), Franchising in the Economy 1985-1987, (prepared by Andrew Kostecka), Washington, D.C.: U.S. Department of Commerce.

Volberda, Henk W. (1996), "Toward the Flexible Firm: How to Remain Vital in Hypercompetitive Environments," Organization Science 7(4), 359-374.

Wathne, Kenneth H. and Jan B. Heide (2004), "Relationship Governance in a Supply Chain Network," Journal of Marketing, 68 (January), 73-89.

Wu, Lawrence (1999), "The Pricing of a Brand Name Product: Franchising In the Motel Services Industry," Journal of Business Venturing, 14, 87-102. 
Table 1

Some Measures of Performance in the Franchising Literature

\begin{tabular}{|c|c|c|}
\hline $\begin{array}{l}\text { Performance Measure - } \\
\text { Type }\end{array}$ & Some Examples & Strength and Weaknesses \\
\hline $\begin{array}{l}\text { Survey-based attitudinal } \\
\text { and perceptual data }\end{array}$ & $\begin{array}{l}\text { Perceived Performance } \\
\text { (Kidwell et al 2007), } \\
\text { Consumer rated quality } \\
\text { (Michael 2000) }\end{array}$ & $\begin{array}{l}\text { These measures are important in that they } \\
\text { allow for the measurement of aspects of } \\
\text { performance that cannot be captured using } \\
\text { other approaches. However, there are } \\
\text { situations where methodological concerns } \\
\text { arise regarding the use of self-reported } \\
\text { attitudinal and perceptual measures } \\
\text { (compared to measures derived from archival } \\
\text { data). }\end{array}$ \\
\hline $\begin{array}{l}\text { Based on archival, } \\
\text { internal data }\end{array}$ & $\begin{array}{l}\text { Revenues per room } \\
\text { (Kalnins 2004). }\end{array}$ & $\begin{array}{l}\text { These measures often have the advantage of } \\
\text { being fine-grained, cover operational as well } \\
\text { as financial domains, and allow for a precise } \\
\text { assessment of performance. However, they } \\
\text { are industry-specific and do not facilitate } \\
\text { comparisons across industries or multiple } \\
\text { industry studies. }\end{array}$ \\
\hline $\begin{array}{l}\text { Based on archival, } \\
\text { publicly available } \\
\text { financial data }\end{array}$ & $\begin{array}{l}\text { Return on assets and } \\
\text { market-to-book value } \\
\text { (Combs and Ketchen Jr. } \\
\text { 1999a); Intangible value } \\
\text { (Srinivasan 2006); Sharpe } \\
\text { ratio, Treynor ratio, Sortino } \\
\text { ratio, Upside Potential } \\
\text { ratio, and the Jensen Index } \\
\text { (Madanoglu et al 2011). }\end{array}$ & $\begin{array}{l}\text { These measures enable the comparative } \\
\text { assessment of financial and stock market } \\
\text { performance across multiple industries. } \\
\text { However, in the U.S., the sample is limited to } \\
\text { large, publicly listed franchisors that are very } \\
\text { different from the smaller, privately held } \\
\text { franchisors that constitute the majority of the } \\
\text { franchising universe. }\end{array}$ \\
\hline Survival and failure rates & $\begin{array}{l}\text { Shane 1996; Lafontaine and } \\
\text { Shaw 1998; Shane 1998; } \\
\text { Azoulay and Shane 2001; } \\
\text { Michael and Combs 2008; } \\
\text { Kosová and Lafontaine } \\
2010 .\end{array}$ & $\begin{array}{l}\text { While this approach addresses the important } \\
\text { question of why some franchisors fail and } \\
\text { others survive, Gillis and Castrogiovanni } \\
\text { (2012) note that it does not explain variations } \\
\text { in network size, growth and performance } \\
\text { across surviving franchisors. This gap is } \\
\text { important because: } \\
\text { (a) in the U.S., Blair and Lafontaine (2005, } \\
\text { page } 48 \text { ) found that, in 2001, approximately } \\
45 \% \text { of franchisors operated systems with less } \\
\text { than } 50 \text { units, and approximately } 89 \% \text { of } \\
\text { franchisors operated systems with } 500 \text { or } \\
\text { fewer units. } \\
\text { (b) internationally, Stanworth (1996) and } \\
\text { Perrigot (2004) found that less than } 50 \text { percent } \\
\text { of franchisors that survived failure continued } \\
\text { to grow at healthy rates in the UK and France } \\
\text { respectively. }\end{array}$ \\
\hline
\end{tabular}


Table 2

Agency Cost Reducing Effects of Franchisor Strategies

\begin{tabular}{|c|c|c|c|c|}
\hline & $\begin{array}{c}\text { Franchisor's } \\
\text { Adverse } \\
\text { Selection } \\
\text { Problem } \\
\text { Mitigation }\end{array}$ & $\begin{array}{c}\text { Prospective } \\
\text { Franchisee's } \\
\text { Adverse } \\
\text { Selection } \\
\text { Problem } \\
\text { Mitigation }\end{array}$ & $\begin{array}{c}\text { Franchisor } \\
\text { Moral } \\
\text { Hazard } \\
\text { Mitigation }\end{array}$ & $\begin{array}{c}\text { Extant } \\
\text { Franchisee } \\
\text { Moral } \\
\text { Hazard } \\
\text { Mitigation }\end{array}$ \\
\hline Royalty Rate & + & + & + & + \\
\hline Advertising Fee & + & + & + & + \\
\hline $\begin{array}{c}\text { Franchise Fee and Initial } \\
\text { Investment }\end{array}$ & & + & + & + \\
\hline $\begin{array}{c}\text { Percentage of Owned } \\
\text { Outlets }\end{array}$ & + & + & + & + \\
\hline Complexity & + & + & & + \\
\hline $\begin{array}{c}\text { Concept Development } \\
\text { Time }\end{array}$ & + & & & + \\
\hline Qualification & + & & + & + \\
\hline Structural Flexibility & + & & & + \\
\hline
\end{tabular}


Table 3

Operationalizations of Constructs

\begin{tabular}{|c|c|c|}
\hline Construct/Variable & Hypotheses & Operationalization \\
\hline Franchisee Network Size & & Total number of franchised outlets in the franchise chain. \\
\hline Royalty Rate & H1 & $\begin{array}{l}\text { Percentage of sales that a franchisee pays as a royalty to the } \\
\text { franchisor on an ongoing basis. }\end{array}$ \\
\hline Advertising Fee & $\mathrm{H} 2$ & $\begin{array}{l}\text { Percentage of sales that a franchisee pays to the franchisor } \\
\text { on an ongoing basis, to be used towards advertising. }\end{array}$ \\
\hline $\begin{array}{l}\text { Franchise Fee and Initial } \\
\text { Investment }\end{array}$ & H3 & $\begin{array}{l}\text { Sum of dollar amount paid by a franchisee to the franchisor } \\
\text { as an up-front franchise fee and the dollar amount of } \\
\text { expenditures incurred by a franchisee to open an outlet. }\end{array}$ \\
\hline Percentage of Owned Outlets & $\mathrm{H} 4$ & $\begin{array}{l}\text { Percentage of franchisor-owned outlets in the franchise } \\
\text { chain. }\end{array}$ \\
\hline Complexity & H5 & $\begin{array}{l}\text { Count of the number of ongoing services provided by the } \\
\text { franchisor to franchisees: } \\
\text { - Central Data Processing } \\
\text { - Central Purchasing } \\
\text { - Field Operations Evaluation } \\
\text { - Field Training } \\
\text { - Initial Store Opening } \\
\text { - Inventory Control } \\
\text { - Franchisee Newsletter } \\
\text { - Regional or National Meetings } \\
\text { - } 800 \text { Telephone Hotline } \\
\text { (Source: Shane, 1998) }\end{array}$ \\
\hline Concept Development Time & H6 & $\begin{array}{l}\text { Gap, in years, between the calendar year of system } \\
\text { establishment and calendar year of first franchise sale } \\
\text { (Source: Lafontaine and Shaw, 1998) }\end{array}$ \\
\hline Qualification & $\mathrm{H} 7$ & $\begin{array}{l}\text { Summation of franchisor ratings (Unimportant=1, Very } \\
\text { Important=5) of the importance of criteria used to qualify } \\
\text { potential franchisees. The following criteria were evaluated: } \\
\text { - Financial Net Worth } \\
\text { - General Business Experience } \\
\text { - Specific Industry Experience } \\
\text { - Formal Education } \\
\text { - Psychological Profile } \\
\text { - Personal Interview } \\
\text { (Source: based on Wathne and Heide, 2004) }\end{array}$ \\
\hline Structural Flexibility & $\mathrm{H} 8$ & $\begin{array}{l}\text { Count of the number of Yeses }(Y e s=1, \text { No }=0) \text { for } \\
\text { - Area Development Permitted? } \\
\text { - Sub Franchising Permitted? } \\
\text { - Expansion in Territory Permitted? } \\
\text { - Conversions Permitted? }\end{array}$ \\
\hline Franchisor Age & & $\begin{array}{l}\text { Current calendar year minus calendar year of the first } \\
\text { franchise sale by the franchisor }\end{array}$ \\
\hline Franchisor Organization Size & & Size of Corporate (Franchisor) Staff \\
\hline Percentage of Outlets in U.S. & & Percentage of U.S. Outlets Relative to Total Outlets. \\
\hline $\begin{array}{c}\text { Franchisee Network Size in } \\
\text { Previous year }\end{array}$ & & $\begin{array}{l}\text { Total number of franchised outlets in the franchise chain in } \\
\text { the previous year. }\end{array}$ \\
\hline
\end{tabular}


Table 4

Descriptive Statistics and Correlation Coefficients

\begin{tabular}{|c|c|c|c|c|c|c|c|c|c|c|c|c|c|c|}
\hline & Variable & $\begin{array}{c}\text { Mean } \\
{\text { (Std. Dev. }{ }^{1}}^{\text {Std }}\end{array}$ & & & & & & & & & & & & \\
\hline & & & (1) & (2) & (3) & (4) & (5) & (6) & (7) & (8) & (9) & (10) & (11) & (12) \\
\hline$(1)$ & $\begin{array}{c}\text { Franchisee } \\
\text { Network Size }\end{array}$ & $\begin{array}{c}176.41 \\
(208.85)\end{array}$ & 1 & & & & & & & & & & & \\
\hline$(2)$ & Royalty Rate & $\begin{array}{c}5.91 \\
(4.42)\end{array}$ & 0.05 & 1 & & & & & & & & & & \\
\hline (3) & $\begin{array}{c}\text { Advertising } \\
\text { Fee }\end{array}$ & $\begin{array}{c}1.53 \\
(1.60)\end{array}$ & 0.01 & -0.16 & 1 & & & & & & & & & \\
\hline (4) & $\begin{array}{c}\text { Franchise Fee } \\
\text { and } \\
\text { Initial } \\
\text { Investment }\end{array}$ & $\begin{array}{c}224,789.80 \\
(310,304.60)\end{array}$ & 0.11 & -0.07 & 0.15 & 1 & & & & & & & & \\
\hline$(5)$ & $\begin{array}{c}\text { Percentage of } \\
\text { Owned } \\
\text { Outlets }\end{array}$ & $\begin{array}{c}11.34 \\
(18.58)\end{array}$ & -0.20 & -0.15 & 0.03 & 0.14 & 1 & & & & & & & \\
\hline (6) & Complexity & $\begin{array}{c}6.71 \\
(1.35)\end{array}$ & 0.001 & -0.03 & 0.16 & 0.27 & 0.10 & 1 & & & & & & \\
\hline (7) & $\begin{array}{c}\text { Concept } \\
\text { Development } \\
\text { Time }\end{array}$ & $\begin{array}{c}5.61 \\
(8.85)\end{array}$ & -0.06 & -0.06 & 0.07 & 0.03 & 0.11 & 0.12 & 1 & & & & & \\
\hline$(8)$ & Qualification & $\begin{array}{l}19.84 \\
(3.58)\end{array}$ & 0.77 & 0.07 & 0.12 & 0.17 & -0.20 & 0.15 & 0.03 & 1 & & & & \\
\hline (9) & $\begin{array}{c}\text { Structural } \\
\text { Flexibility }\end{array}$ & $\begin{array}{c}2.29 \\
(1.00)\end{array}$ & 0.80 & 0.07 & 0.10 & 0.18 & -0.18 & 0.12 & 0.94 & 0.02 & 1 & & & \\
\hline (10) & $\begin{array}{c}\text { Franchisor } \\
\text { Age }\end{array}$ & $\begin{array}{c}24.38 \\
(10.70)\end{array}$ & 0.33 & 0.19 & 0.12 & 0.21 & -0.17 & -0.07 & 0.36 & -0.07 & 0.36 & 1 & & \\
\hline$(11)$ & $\begin{array}{c}\text { Franchisor } \\
\text { Organization } \\
\text { Size }\end{array}$ & $\begin{array}{c}37.33 \\
(60.88)\end{array}$ & 0.33 & 0.16 & -0.02 & 0.19 & 0.13 & 0.11 & 0.40 & 0.19 & 0.39 & 0.29 & 1 & \\
\hline (12) & $\begin{array}{l}\text { Percentage of } \\
\text { Outlets } \\
\text { in U.S. }\end{array}$ & $\begin{array}{c}79.73 \\
(33.91)\end{array}$ & 0.44 & 0.05 & 0.16 & 0.19 & -0.18 & 0.22 & 0.82 & 0.02 & 0.77 & 0.27 & 0.29 & 1 \\
\hline
\end{tabular}

${ }^{1}$ The number of observations for each variable $=9 \times 76=684$ 
Table 5

Tests for Panel Unit Root

\begin{tabular}{|l|c|c|}
\hline \multicolumn{1}{|c|}{ Variable } & Hypotheses & \multicolumn{1}{|c|}{$\begin{array}{c}\text { Unit Root Test } \\
\text { (Levin et al, 2002) }\end{array}$} \\
\hline Franchisee Network Size & & 0.0000 \\
\hline Royalty Rate & H1 & 0.0000 \\
\hline Advertising Fee & H2 & 0.0005 \\
\hline $\begin{array}{l}\text { Franchise Fee and Initial } \\
\text { Investment }\end{array}$ & H3 & 0.0000 \\
\hline Percentage of Owned Outlets & H4 & 0.0000 \\
\hline Complexity & H5 & 0.0000 \\
\hline Concept Development Time & H6 & 0.0010 \\
\hline Qualification & H7 & 0.0000 \\
\hline Structural Flexibility & H8 & 0.0000 \\
\hline Franchisor Age & & 0.0005 \\
\hline Franchisor Organization Size & & 0.0000 \\
\hline Percentage of Outlets in U.S. & & 0.0000 \\
\hline $\begin{array}{l}\text { Franchisee Network Size in } \\
\text { previous year }\end{array}$ & & 0.0000 \\
\hline
\end{tabular}

NOTE: The results of the Levin et al (2002) unit root test with individual effects included in the test equation indicate that the null hypothesis of a common panel unit root can be rejected for every variable. In other words, all variables can be treated as stationary. Thus, there is no spurious regression problem and there is no need to test for panel cointegration. 
Table 6

Summary of Hypotheses and Estimation Results

\begin{tabular}{|c|c|c|c|}
\hline $\begin{array}{l}\text { Independent } \\
\text { variable }\end{array}$ & Hypotheses & Hypothesized Effect & $\begin{array}{l}\text { Arellano \& Bover } \\
\text { Dynamic panel } \\
\text { GMM; White } \\
\text { period robust SEs* } \\
\text { Coefficient } \\
\text { (Sig) }\end{array}$ \\
\hline Royalty Rate & H1 & + & $\begin{array}{c}22.6 \\
(0.0000)\end{array}$ \\
\hline Advertising Fee & $\mathrm{H} 2$ & + & $\begin{array}{c}56.05 \\
(0.0000)\end{array}$ \\
\hline $\begin{array}{l}\text { Franchise Fee and } \\
\text { Initial Investment }\end{array}$ & H3 & + & $\begin{array}{l}-0.00004 \\
(0.0000)\end{array}$ \\
\hline $\begin{array}{l}\text { Percentage of } \\
\text { Owned Outlets }\end{array}$ & $\mathrm{H} 4$ & - & $\begin{array}{c}-7.87 \\
(0.0000)\end{array}$ \\
\hline Complexity & H5 & + & $\begin{array}{c}19.82 \\
(0.0001)\end{array}$ \\
\hline $\begin{array}{c}\text { Concept } \\
\text { Development } \\
\text { Time }\end{array}$ & H6 & + & $\begin{array}{c}2.82 \\
(0.0076)\end{array}$ \\
\hline Qualification & $\mathrm{H} 7$ & + & $\begin{array}{c}45.97 \\
(0.0068)\end{array}$ \\
\hline $\begin{array}{l}\text { Structural } \\
\text { Flexibility }\end{array}$ & $\mathrm{H} 8$ & + & $\begin{array}{c}10.83 \\
(0.0326)\end{array}$ \\
\hline Franchisor Age & & & $\begin{array}{c}-2.22 \\
(0.0089)\end{array}$ \\
\hline $\begin{array}{c}\text { Franchisor } \\
\text { Organization Size }\end{array}$ & & & $\begin{array}{c}1.78 \\
(0.0000)\end{array}$ \\
\hline $\begin{array}{l}\text { Percentage of } \\
\text { Outlets in U.S. }\end{array}$ & & & $\begin{array}{c}0.24 \\
(0.3837)\end{array}$ \\
\hline \multirow[t]{2}{*}{$\begin{array}{c}\text { Franchisee } \\
\text { Network Size in } \\
\text { Previous Year }\end{array}$} & & & $\begin{array}{c}0.17 \\
(0.0000)\end{array}$ \\
\hline & & & $\begin{array}{c}\text { Sargan test** } \\
\text { p-value }=0.1946\end{array}$ \\
\hline
\end{tabular}

*White period robust SEs are robust to innovations that have time series correlation structure that varies by cross-section.

**Sargan test: null hypothesis is that the over-identifying restrictions are valid.

Note: One-sided p-values are reported in parentheses. Instruments include lags of endogenous variables, all exogenous variables, and dynamic period-specific (predetermined) instruments. 
FIGURE 1: THEORETICAL FRAMEWORK

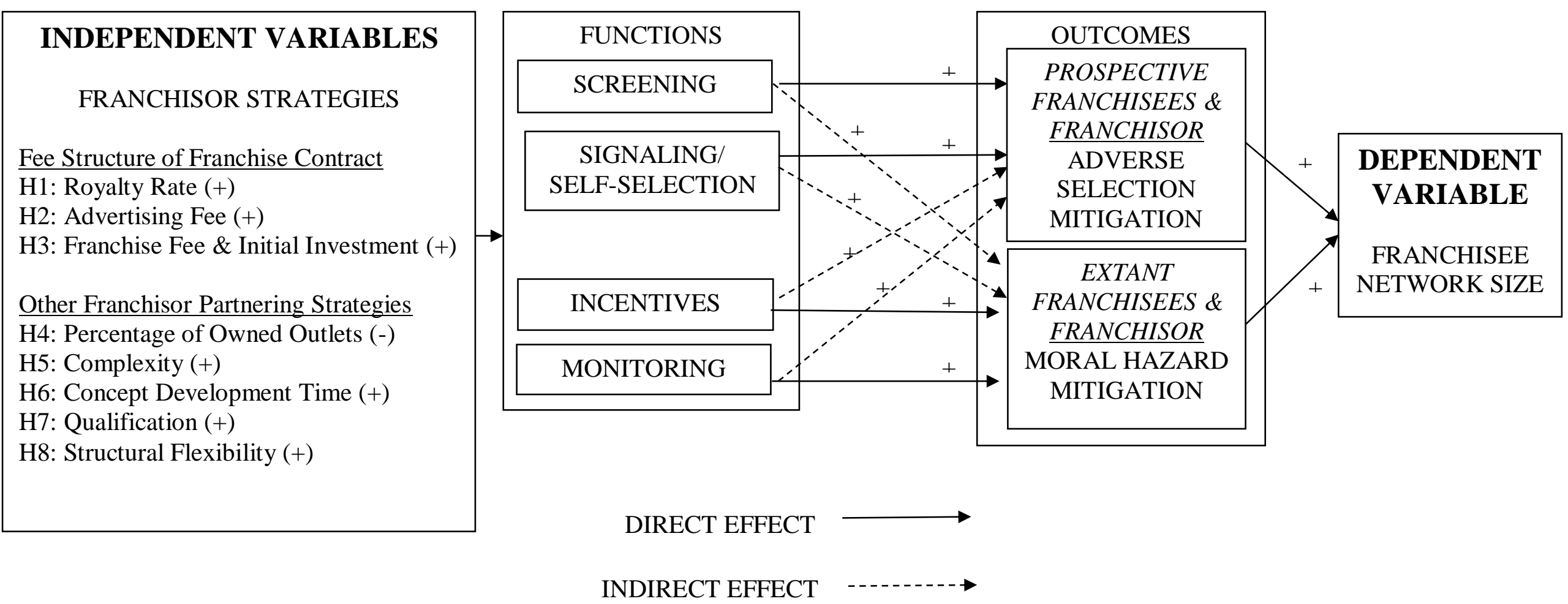




\title{
How Firm Strategies Impact Size of Partner-Based Retail Networks: Evidence from Franchising
}

\author{
Manish Kacker ${ }^{1}$ \\ Associate Professor, Marketing \\ Michael Lee-Chin \& Family Professor in Strategic Business Studies \\ DeGroote School of Business, McMaster University \\ 1280 Main St. W. Hamilton, ON, L8S-4M4 Canada \\ Voice: 905-525-9140 x 21658 Facsimile: 905-521-8995 \\ Email:mkacker@mcmaster.ca \\ Rajiv P. Dant \\ Division Director \& Michael F. Price Chair in Business \\ Division of Marketing and Supply Chain Management \\ Michael F. Price College of Business, The University of Oklahoma \\ 307 West Brooks, Norman, OK 73019-4001 USA \\ Voice: 405-325-4675 Facsimile: 405-325-7688 \\ Email: $\underline{\text { rdant @ou.edu }}$ \\ Jamie Emerson \\ Associate Professor of Economics \\ Department of Economics and Finance \\ Perdue School of Business, Salisbury University \\ Salisbury, MD 21801-6860 USA \\ Voice: 410-677-6578 Facsimile: 410-548-2908 \\ Email: jdemerson@salisbury.edu \\ Anne T. Coughlan \\ John L. and Helen Kellogg Professor of Marketing \\ Kellogg School of Management, Northwestern University \\ 2001 Sheridan Road, Evanston, IL 60208-2008 USA \\ Voice: 847-491-2719 Facsimile: 847-491-2498 \\ Email: a-coughlan@kellogg.northwestern.edu
}

March 2014

Forthcoming in the Journal of Small Business Management

KEYWORDS: Franchising, Marketing Channels, Partnering Strategies, Retailing, Agency Theory, Organizational Performance, Econometric Analysis, Dual Distribution.

\footnotetext{
${ }^{1}$ Corresponding author.
} 